\title{
Evidence of serologic activity in chronic hepatitis $B$ after surface antigen (HBsAg) seroclearance documented by conventional HBsAg assay
}

\author{
Wai-Kay Seto $\cdot$ Yasuhito Tanaka $\cdot$ Danny Ka-Ho Wong $\cdot$ Ching-Lung Lai \\ Noboru Shinkai · John Chi-Hang Yuen · Teresa Tong • James Fung • \\ Ivan Fan-Ngai Hung • Man-Fung Yuen
}

Received: 4 October 2011/ Accepted: 21 February 2012/Published online: 13 March 2012

(C) Asian Pacific Association for the Study of the Liver 2012

\begin{abstract}
Background Possible serologic activity after hepatitis B surface antigen ( $\mathrm{HBsAg})$ seroclearance documented by conventional assays in chronic hepatitis B ( $\mathrm{CHB}$ ) has not been thoroughly investigated.

Methods We determined the levels of serum hepatitis B virus (HBV) DNA, hepatitis B core-related antigen (HBcrAg), and linearized HBsAg (CLEIA prototype) in 329 CHB patients (72.0\% male) after HBsAg seroclearance was documented by a conventional HBsAg assay.

Results The median interval between presentation and HBsAg seroclearance was 69.4 months. The median age at HBsAg seroclearance was 50 years. Assays for serum HBV DNA, HBcrAg, and linearized HBsAg were performed at a median time interval of 11.2 months after HBsAg loss. Linearized HBsAg and HBcrAg were detectable in $85(25.8 \%)$ and $69(21 \%)$ patients, respectively, and one or both serologic markers were detectable in 133 patients (40.4\%). Serum HBV DNA was detectable in only 7 patients $(2.1 \%)$. There was no correlation between linearized HBsAg and HBcrAg levels $(r=0.095$,
\end{abstract}

W.-K. Seto - D. K.-H. Wong - C.-L. Lai ·

J. C.-H. Yuen · T. Tong - J. Fung · I. F.-N. Hung ·

M.-F. Yuen $(\square)$

Department of Medicine, Queen Mary Hospital,

The University of Hong Kong, Pokfulam Road,

Hong Kong, China

e-mail: mfyuen@hkucc.hku.hk

Y. Tanaka $\cdot$ N. Shinkai

Department of Virology and Liver Unit, Nagoya City University

Graduate School of Medical Sciences, Nagoya, Japan

C.-L. Lai · M.-F. Yuen

State Key Laboratory for Liver Research, Queen Mary Hospital,

The University of Hong Kong, Hong Kong, China $p=0.924)$. The incidences of detectable linearized HBsAg and $\mathrm{HBcrAg}$ did not differ between patient samples taken at 6-12 and >12 months after HBsAg seroclearance ( $p=0.146$ and 0.079 , respectively). Among patients with detectable serologic markers, median levels of linearized HBsAg $(p=0.581)$ and HBcrAg $(p=0.951)$ did not significantly change with time after HBsAg seroclearance. Conclusion Using novel HBcrAg and linearized HBsAg assays, viral serologic activity after HBsAg seroclearance was demonstrated in more than $40 \%$ of CHB patients. These tests have potential applications in diagnosing and prognosticating CHB patients with HBsAg seroclearance.

Keywords HBsAg - Linearized HBsAg - Serology · Seroclearance $\cdot$ HBcrAg

\section{Introduction}

Seroclearance of the hepatitis B surface antigen (HBsAg) is an uncommon event in the natural history of chronic hepatitis $\mathrm{B}$ (CHB), with its incidence ranging from 0.1 to $2.26 \%$ per year throughout the world [1-3]. Despite being the ultimate treatment endpoint for CHB, HBsAg seroclearance is only seen in $7 \%$ of patients after pegylated interferon therapy [4] and 1.4 to $8 \%$, after long-term nucleoside analogue therapy $[5,6]$. Even after HBsAg seroclearance, the hepatitis B virus (HBV) is still present at a low replicative level [7, 8], and patients are still at risk to the development of hepatocellular carcinoma (HCC) $[9,10]$.

An important determinant in the rates of $\mathrm{HBsAg}$ seroclearance would be the sensitivity of the HBsAg assay. The standard method used currently in commercial assays is the enzyme-linked immunoassay (ELISA), which has the 
advantage of simplicity. Over the past two decades, there has been a gradual improvement in the assay's sensitivity, with the majority of commercial assays achieving a lower limit of detection of $0.05 \mathrm{IU} / \mathrm{mL}[11,12]$. However, the detection of HBsAg is still not flawless. Conventional HBsAg assays only target one epitope, i.e., the common determinant "a"; excluding other potential epitopes, which might lower the assay's sensitivity [13]. A second factor determining the assay's sensitivity would be its capability in detecting HBsAg mutants [14], in which amino acid substitution within the "a" determinant could give false negative results. The development of the hepatitis B corerelated antigen $(\mathrm{HBcrAg})$ assay has resulted in an additional option in the serologic monitoring of CHB [15]. Based on the simultaneous detection of both hepatitis $\mathrm{B}$ e antigen $(\mathrm{HBe} \mathrm{Ag})$ and hepatitis $\mathrm{B}$ core antigen $(\mathrm{HBcAg})$, the HBcrAg assay has been shown to correlate well with serum HBV DNA, intrahepatic HBV DNA, and covalently closed circular DNA (cccDNA), reflecting actual histologic severity in CHB [16]. It is not affected by HBeAg status or the emergence of $\mathrm{HBeAg}$-negative precore mutations [17].

A recent study employed an innovative and highly sensitive chemiluminescent enzyme immunoassay (CLEIA) for the quantitative detection of HBsAg (prototype) [18]. Using a combination of monoclonal antibodies, targeting both the exposed common determinant "a" of the surface antigen and the epitope embedded inside the lipid bilayer of the viral envelope, this linearized HBsAg assay is able to identify HBsAg mutants that evade detection by current serologic assays [13]. Linearized HBsAg has been shown to demonstrate good correlation with conventional HBsAg assays, and in patients receiving nucleoside analogue therapy, was able to detect HBsAg in the serum after documented HBsAg seroclearance by conventional assays [19]. In addition, linearized HBsAg is 10 times more sensitive than current conventional $\mathrm{HBsAg}$ assays, with a lower limit of detection of $0.005 \mathrm{IU} / \mathrm{mL}$. In our current study, we propose studying the serologic activity of CHB patients after documented HBsAg seroclearance by a conventional HBsAg assay using both the HBcrAg and linearized HBsAg assays.

\section{Methods}

In the Department of Medicine, the University of Hong Kong, Queen Mary Hospital, Hong Kong, all CHB patients followed up at our clinic underwent tests for serum HBsAg, antibody to HBsAg (anti-HBs), HBeAg, antibody to $\mathrm{HBeAg}$ (anti-HBe), liver biochemistry, and alpha-fetoprotein every 6 months. From September 1990 to April 2010, we recruited patients who having had documented HBsAg positivity for at least 6 months were noted to have loss of serum HBsAg by a conventional HBsAg assay (Abbott Laboratories, Chicago, IL, USA) at 2 time points at least 6 months apart, with or without the appearance of serum antibody to HBsAg (anti-HBs). The interval between the last HBsAg-positive result and HBsAg seroclearance for all patients was 6 months. All clinical and biochemical data at initial presentation and during follow-up were recorded. For patients positive for $\mathrm{HBeAg}$ at the initial presentation, the date of HBeAg seroconversion was recorded.

The conventional HBsAg assay has a lower limit of detection of $0.05 \mathrm{IU} / \mathrm{mL}$. Anti-HBs, HBeAg, and anti-HBe were measured using commercially available immunoassays (Abbott Laboratories, Chicago, IL, USA). All patients with concomitant chronic hepatitis $\mathrm{C}$ and $\mathrm{D}$, evidence of Wilson disease, autoimmune hepatitis, primary biliary cirrhosis, and significant intake of alcohol (20 g/day for women and $30 \mathrm{~g} /$ day for men) were excluded. This study was approved by the Institutional Review Board, the University of Hong Kong and West Cluster of Hospital Authority, Hong Kong.

Serum HBV DNA levels, HBcrAg, and linearized HBsAg were measured at a single time point at least 6 months after HBsAg loss was first documented. Serum HBV DNA levels were measured by Cobas Taqman assay (Roche Diagnostics, Branchburg, NJ, USA) with a lower limit of detection of $20 \mathrm{IU} / \mathrm{mL}$. Serum HBcrAg was measured using the CLEIA described previously $[15,16]$. Briefly, sodium dodecyl sulfate pre-treated serum was incubated with monoclonal antibodies against denatured $\mathrm{HBcAg}$ and $\mathrm{HBeAg}$. After washing and incubation with alkaline phosphatase-labeled secondary antibodies, the relative chemiluminescence intensity was measured, and the HBcrAg concentration was calculated by comparing with a standard curve generated using known concentrations of recombinant $\mathrm{HBeAg}$-containing peptides. The cutoff value of $\mathrm{HBcrAg}$ concentration was $1 \mathrm{kU} / \mathrm{mL}$.

Serum linearized HBsAg was measured using an automated technique based on a CLEIA prototype used in a previous study by Matsubara et al. [13]. Briefly, serum or plasma samples with denatured HBsAg were added to micro-ferrite particles coated with anti-HBs monoclonal capture antibodies recognizing both the outer epitope determinant "a" and an inner (normally embedded) epitope. Following incubation and washing, $200 \mu \mathrm{L}$ substrate [AMPPD; 3-(2'-spiroadamantan)-4-methoxy-4-(3'-phosphoryloxy) phenyl-1, 2-dioxetane disodium salt] (Applied Biosystems, Bedford, MA, USA) solution was added and incubated at $37^{\circ} \mathrm{C}$ for $5 \mathrm{~min}$. The relative intensity of chemiluminescence was measured, and the HBsAg concentration was calculated by comparison with an international standard curve. The assay range of $\mathrm{HBsAg}$ concentration in this reagent was $0.005-150 \mathrm{IU} / \mathrm{mL}$, and retest was acceptable by the 200 -fold dilution of sample 
Fig. 1 The difference in viral components measured by different serologic assays used

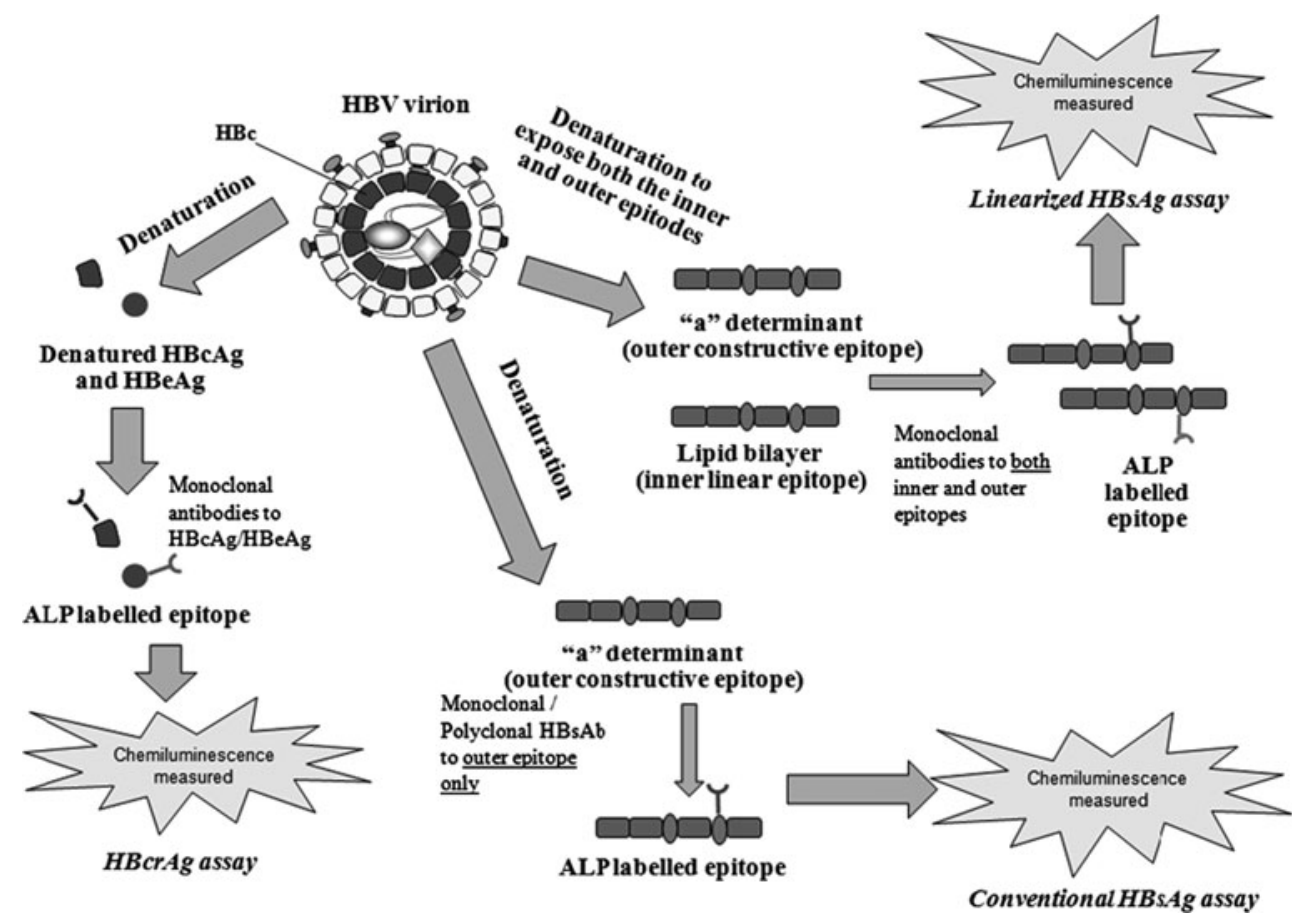

Table 1 Demographics and biochemistry of the studied population at initial presentation

\begin{tabular}{ll}
\hline Number of patients & 329 \\
Male $(\%)$ & $237(72.0)$ \\
Age (years) & $42.7(1.9-79.3)$ \\
HBeAg-positive $(\%)$ & $47(14.3)$ \\
Albumin $(\mathrm{g} / \mathrm{dL})$ & $45(29-56)$ \\
Bilirubin $(\mu \mathrm{mol} / \mathrm{L})$ & $11(3-132)$ \\
ALT $(\mathrm{U} / \mathrm{L})$ & $33(4-1522)$ \\
Cirrhosis $(\%)$ & $8(2.3)$ \\
\hline
\end{tabular}

Continuous variables expressed in median (range)

$A L T$ alanine aminotransferase, $\mathrm{HBeAg}$ hepatitis $\mathrm{B}$ e antigen HBsAg, HBcrAg, and other clinical parameters was tested using Spearman's bivariate correlation. A two-sided $p$ value $<0.05$ was considered statistically significant.

\section{Results}

A total of 388 patients referred to our hospital with prior positive $\mathrm{HBsAg}$ result were noted to have $\mathrm{HBsAg}$ seroclearance using the conventional $\mathrm{HBsAg}$ assay during the recruitment period. By applying the exclusion criteria mentioned above, the following patients were excluded: no positive $\mathrm{HBsAg}$ result recorded in our center $(n=33)$, acute $\mathrm{HBV}$ infection $(n=12)$, subsequent HBsAg reversion $(n=11)$, documented HBsAg negativity $<6$ months $(n=2)$, and HCV co-infection $(n=1)$. Three hundred and twenty-nine patients were eventually recruited for this study. Their baseline demographics and liver biochemistry upon presentation are depicted in Table 1 . The median interval between initial presentation, i.e., first documented learance was 69.4 months (range 6.2-284.2 months).

Forty-seven patients (14.3\%) were initially $\mathrm{HBeAg}$ positive, with $\mathrm{HBeAg}$ seroconversion noted after a median period of 16.3 months (range 1.2-99.6 months). Concerning treatment of $\mathrm{CHB}$, three patients were treated with conventional interferon-alpha for 52 weeks, with all three patients achieving HBsAg seroclearance at least 6 years after completion of interferon therapy. Fourteen patients (13 on lamivudine and 1 on entecavir) had exposure to nucleoside analogues. The remaining 312 patients were all treatment-naïve.

The median age at HBsAg seroclearance was 50 years (range 4.1-84.7 years), with $48.9 \% \quad(n=161)$ patients eventually developing anti-HBs, as assessed at the time of date of HBsAg positivity at our clinic, and HBsAg seroc- 
their last follow-up. The median interval between $\mathrm{HBsAg}$ seroclearance and the appearance of anti-HBs was 20.3 months (range 0-165.7 months). Twelve patients achieved HBsAg seroclearance after a median therapy duration of 46 months (range 18-129 months), while two patients achieved HBsAg loss at 21 and 36 months after the termination of nucleoside analogues.

Linearized HBsAg, HBcrAg, and HBV DNA levels were tested at a median interval of 11.2 months (range 6.0-186.9 months) after HBsAg loss was documented by the conventional HBsAg assay. Sixty-three patients $(19.1 \%)$ had detectable anti-HBs during the testing. The results are depicted in Fig. 2. Eighty-five (25.8\%) and sixty-nine $(21 \%)$ patients had detectable linearized $\mathrm{HBsAg}$ (range 0.005-150 IU/mL) and HBcrAg (range 1-934 $\mathrm{kU} / \mathrm{mL}$ ), respectively, with detectability of either one or both viral proteins in 133 patients $(40.4 \%)$. Twenty-one patients $(6.4 \%)$ had both detectable linearized HBsAg and HBcrAg. The serum tests for linearized HBsAg and $\mathrm{HBcrAg}$ were performed at a median period of 10 (range 6-118) and 11 (range 6-186.9) months after HBsAg seroclearance, respectively. Among patients with prior nucleoside analogue exposure $(n=2)$ or with nucleoside analogue therapy at the time of $\mathrm{HBsAg}$ seroclearance $(n=12)$, six and seven patients had detectable linearized HBsAg and HBcrAg, respectively. Only seven patients (2.1\%) within the total patient cohort had detectable HBV DNA (range 20-1,594 IU/mL). Among these seven patients, five had detectable linearized HBsAg levels, while none had detectable HBcrAg levels.

Among the 244 patients without detectable linearized HBsAg, 48 (19.7\%) had detectable HBcrAg, with the median interval of measurement after HBsAg seroclearance being 12 (range 6-136.3) months. There were also

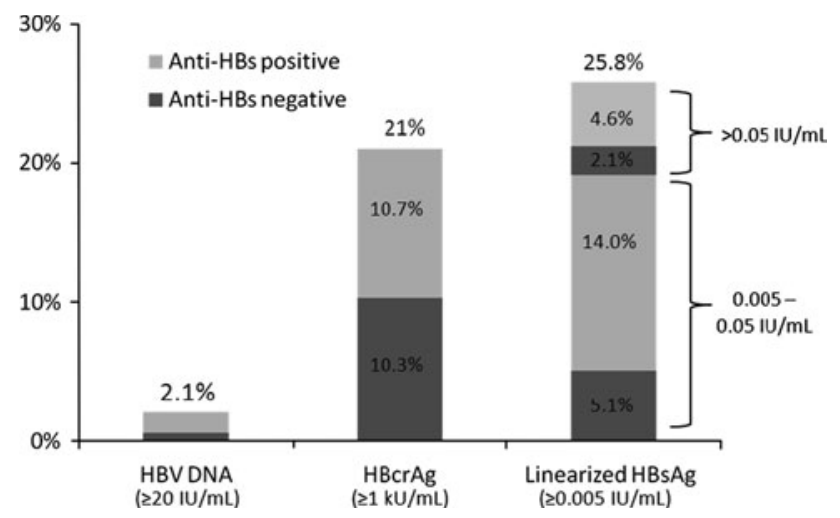

Fig. 2 Percentage of patients with detectable viremia and viral proteins after HBsAg seroclearance documented by a conventional assay $(n=329)$. HBsAg hepatitis $\mathrm{B}$ surface antigen, anti-HBs antibody to the hepatitis B surface antigen, HBcrAg hepatitis B core-related antigen
Table 2 Percentage of patients with detectable serological markers among patients with and without eventual development of anti-HBs

\begin{tabular}{llll}
\hline & $\begin{array}{l}\text { Anti-HBs positive } \\
\text { patients }(n=161)\end{array}$ & $\begin{array}{l}\text { Anti-HBs } \\
\text { negative } \\
\text { patients } \\
(n=168)\end{array}$ & $p$ value \\
\hline $\begin{array}{l}\text { Positive } \\
\text { linearized }\end{array}$ & $24(14.9 \%)$ & $61(36.3 \%)$ & $<0.001$ \\
$\begin{array}{l}\text { HBsAg } \\
\text { Positive HBcrAg }\end{array}$ & $34(21.1 \%)$ & $35(20.8 \%)$ & 0.949 \\
\hline
\end{tabular}

two patients $(0.8 \%)$ with detectable serum HBV DNA at 6.5 and 42 months after HBsAg seroclearance.

The association of the eventual appearance of anti-HBs and detectable viral proteins is depicted in Table 2. When compared to anti-HBs positive patients, a significantly higher proportion of anti-HBs negative patients had detectable linearized HBsAg $(p<0.001)$. There was no significant difference in the percentage of patients with detectable HBcrAg between the two groups $(p=0.949)$.

Linearized HBsAg levels showed no correlation with HBcrAg levels $(r=0.095, p=0.924)$. Both linearized HBsAg and HBcrAg levels also showed no correlation with gender $(r=-0.02$ and $-0.04, p=0.711$ and 0.462 , respectively).

The percentage of patients with detectable linearized HBsAg and HBcrAg according to the interval between HBsAg seroclearance and serological testing is shown in Table 3. The incidences of detectable linearized HBsAg and HBcrAg did not significantly differ with time after HBsAg seroclearance at 12,24 , and 36 months $(p>0.05)$. Detectable linearized HBsAg and HBcrAg levels from the time of HBsAg seroclearance are shown in Fig. 3a and b. Among patients with detectable serological markers, the median levels of linearized $\operatorname{HBsAg}(p=0.581)$ and HBcrAg $(p=0.951)$ did not change significantly with time after HBsAg seroclearance.

\section{Discussion}

Our present study showed that at least $40 \%$ of $\mathrm{CHB}$ patients with documented $\mathrm{HBsAg}$ seroclearance using a conventional HBsAg assay had demonstrable serologic activity indicative of continuous viral transcription.

Older age is an established predisposing factor for HBsAg seroclearance $[2,10]$. Despite a low annual incidence rate, the cumulative rate of $\mathrm{HBsAg}$ seroclearance after 25 years could reach up to $40 \%$ according to a Taiwan study consisting of 1,965 Chinese CHB patients [20]. Therefore, in an endemic region where the prevalence of positive antibody to the hepatitis B core antigen (anti-HBc) 
Table 3 Percentage of detectable linearized HBsAg and HBcrAg after HBsAg seroclearance

\begin{tabular}{|c|c|c|c|c|}
\hline \multirow[t]{2}{*}{ Time from HBsAg seroclearance (months) } & \multicolumn{2}{|l|}{ Linearized HBsAg } & \multicolumn{2}{|l|}{ HBcrAg } \\
\hline & Detectable percentage (ratio) & $p$ value & Detectable percentage (ratio) & $p$ value \\
\hline \multicolumn{5}{|l|}{ a: 12 months } \\
\hline$\leq 12$ & $29.1 \%(52 / 179)$ & 0.146 & $24.6 \%(44 / 179)$ & 0.079 \\
\hline$>12$ & $28.2 \%(33 / 150)$ & & $20.0 \%(25 / 125)$ & \\
\hline \multicolumn{5}{|l|}{ b: 24 months } \\
\hline$\leq 24$ & $28.4 \%(71 / 250)$ & 0.076 & $20.0 \%(50 / 250)$ & 0.441 \\
\hline$>24$ & $17.7 \%(14 / 79)$ & & $24.1 \%(19 / 79)$ & \\
\hline \multicolumn{5}{|l|}{ c: 36 months } \\
\hline$\leq 36$ & $25.8 \%(73 / 283)$ & 0.901 & $20.1 \%(57 / 283)$ & 0.358 \\
\hline$>36$ & $26.1 \%(12 / 46)$ & & $26.1 \%(12 / 46)$ & \\
\hline
\end{tabular}

Patients were divided into two groups for analyses based on the time of measurement after HBsAg seroclearance as documented by a conventional HBsAg assay: 12 months (a), 24 months (b), and 36 months (c)

$H B s A g$ hepatitis B surface antigen, HBcrAg hepatitis B core-related antigen

is reported to be between 13.5 and $17 \%$ [21-23], it may be difficult to differentiate CHB patients with HBsAg seroclearance and those with prior exposure to HBV, especially for persons older than 50 years (the median age of $\mathrm{HBsAg}$ loss). Although serum HBV DNA testing is an option for differentiation, the likelihood of a positive HBV DNA result is low as shown in our study (2.1\%). Even when the lower limit of detection was improved to $1.1 \mathrm{IU} / \mathrm{mL}$, the chance of $\mathrm{HBV}$ DNA positivity was still only $13.4 \%$ [9]. The HBcrAg and linearized HBsAg assays would be a useful tool in diagnosing CHB patients with prior HBsAg seroclearance documented by conventional HBsAg assay before the initial clinical presentation, especially since our present study showed the two viral proteins could be detected up to 118 and 187 months after HBsAg seroclearance.

Our present study found that the percentage of detectable serologic markers remained similar in serum samples taken at different time points after HBsAg loss. Moreover, the median levels of both viral proteins among patients with detectable markers after HBsAg seroclearance remained similar over time. Our results suggest that there is persistent low-grade viral transcriptional activity for years after HBsAg seroclearance. In addition, the concept of HBsAg seroclearance might need refinement, given that $25.8 \%$ patients with documented HBsAg seroclearance using a conventional assay had a positive linearized HBsAg result. However, it should be noted that these findings are limited by the cross-sectional nature of our study, with the serum of patients taken at different time intervals after HBsAg seroclearance. Longitudinal studies with serial viral protein levels are needed and would be useful to further investigate the relationship of anti-HBs with linearized HBsAg.

The pathophysiology of continued viral protein production after HBsAg seroclearance is not well-defined. The presence of viral escape mutants in the "a" determinant is possible [24]. Although the majority of mutants are detectable by current serologic assays, detection limits of HBsAg mutants vary between different assays [25]. HBsAg production exceeds the required amount for virion assembly of the Dane particle, and can also be secreted as empty subviral particles [26, 27]. These subviral particles have been suggested to be involved in the immune evasion strategy of HBV [28], and could remain in circulation even when the production of virions decreases [29], as in $\mathrm{HBsAg}$ seroclearance. In $\mathrm{CHB}$ patients achieving $\mathrm{HBsAg}$ seroclearance, intrahepatic cccDNA is still detectable at extremely low levels [9]. Serum HBcrAg levels had been previously proven to have good correlation with intrahepatic cccDNA levels [16]. Despite earlier evidence of good correlation between serum HBsAg and intrahepatic cccDNA [30, 31], a recent study did not find such a correlation in $\mathrm{HBeAg}$-negative disease [32], probably since viral integration, a non-essential event in the life cycle of $\mathrm{HBV}$, produces HBsAg in the absence of viral replication [33]. Hence, it is not surprising that studies have shown that there is no significant HBsAg decline in CHB patients treated with nucleoside analogues [34]. Further studies are needed to determine if any correlation exists between linearized HBsAg levels and intrahepatic cccDNA.

Identifying patients with prior $\mathrm{HBsAg}$ seroclearance as documented by a conventional assay carries several clinical implications. First, an older age at $\mathrm{HBsAg}$ seroclearance is still associated with risk of $\mathrm{HCC}[9,10]$, thus detecting past HBsAg seroclearance would facilitate the enlisting of such patients into HCC surveillance programs. Second, fulminant $\mathrm{HBV}$ reactivation is possible in $\mathrm{HBsAg}$-negative but anti-HBc positive patients undergoing immunosuppression or chemotherapy, especially for regimens containing rituximab [35]. Identifying patients with prior $\mathrm{HBsAg}$ 
Fig. 3 Detectable linearized HBsAg (a) and HBcrAg (b) levels after HBsAg seroclearance as documented by a conventional HBsAg assay

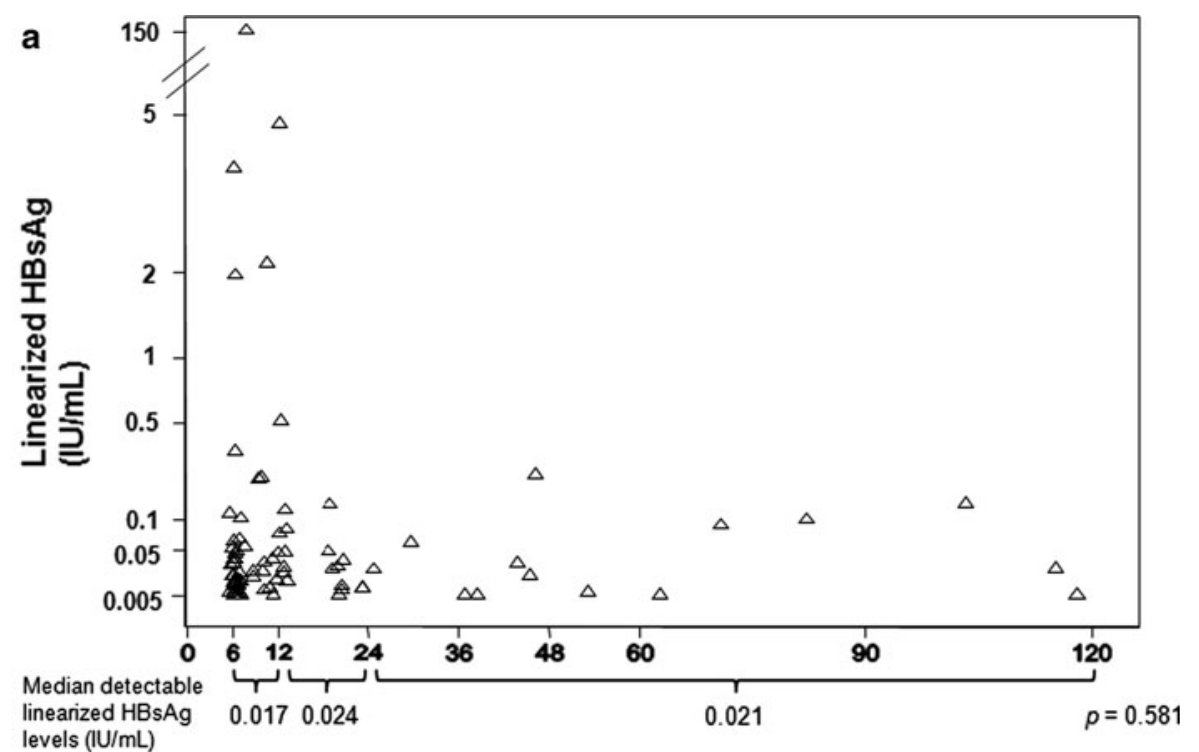

Time after HBsAg seroclearance (months) $(n=85)$

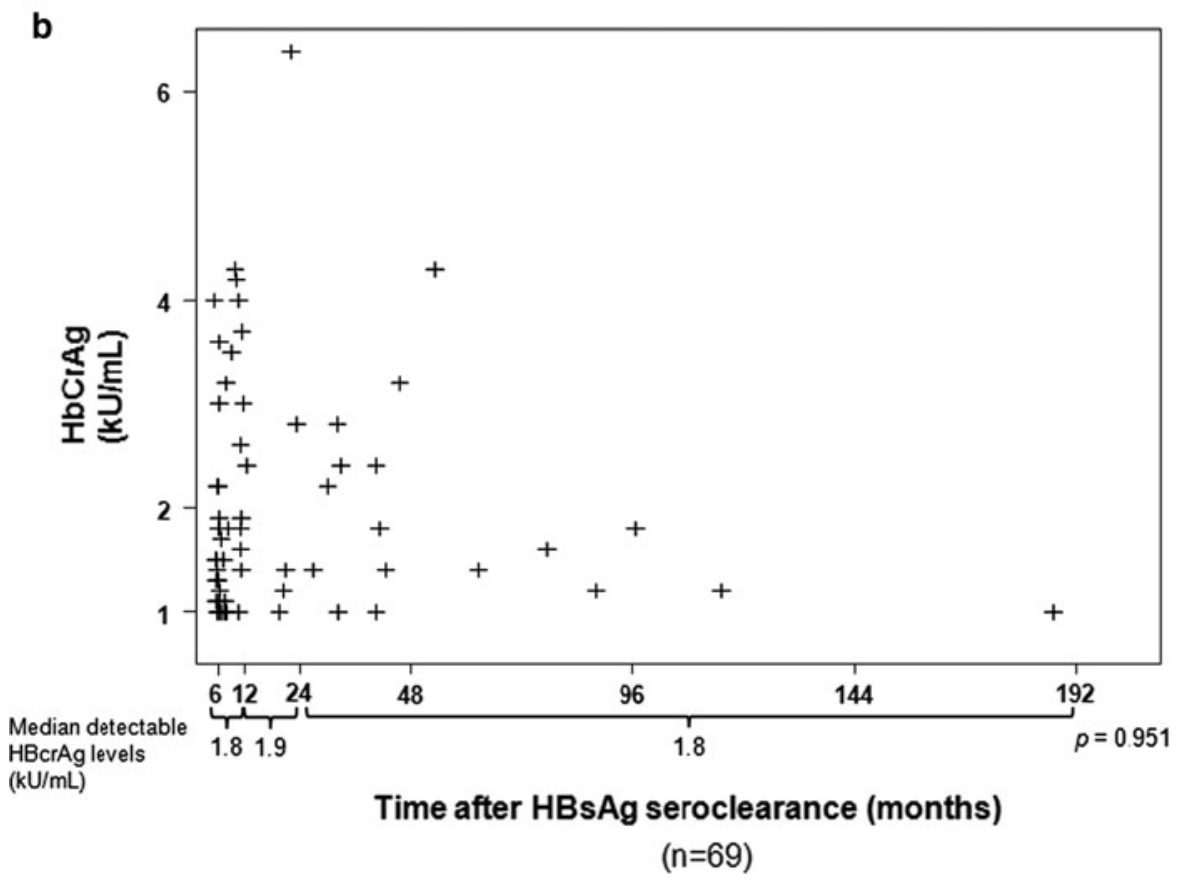

seroclearance would allow either preemptive antiviral therapy or close serologic and virologic monitoring. Third, using both HBcrAg and linearized HBsAg assays, over $40 \%$ of CHB patients with prior HBsAg seroclearance could be identified. Detectable HBcrAg and linearized HBsAg in patients considered to have cryptogenic cirrhosis will reveal the actual diagnosis to be occult hepatitis B infection. Future studies could further investigate the relationship of these two novel serologic markers with both serum anti-HBs and anti-HBc.

There are several limitations of this study, the first being its cross-sectional nature as mentioned above. HBV genotypes were not checked in our study. Since genotype-specific changes were found in HBsAg levels during pegylated interferon treatment [36], it would be interesting to determine the effect of genotype on the kinetics of viral protein production after HBsAg seroclearance. Baseline HBV DNA levels were not available in our present study. A previous study in Asian CHB patients found low HBV DNA levels to be predictive of eventual HBsAg seroclearance [2], and therefore, such data should be included in future longitudinal studies concerning these two serologic markers. 
In conclusion, the detection of $\mathrm{HBcrAg}$ and linearized HBsAg in more than $40 \%$ of CHB patients achieving HBsAg seroclearance documented by a conventional HBsAg assay suggests that transcription of viral proteins still exists even when serum HBsAg is undetectable. These two novel assays can assist the diagnosis of CHB patients with prior HBsAg seroclearance. Further longitudinal studies are needed to determine if these two serologic markers have prognostic implications for both treated and untreated CHB patients.

Conflict of interest No conflicts of interest exist for all authors.

\section{References}

1. McMahon BJ, Alberts SR, Wainwright RB, et al. Hepatitis B-related sequelae. Prospective study in 1,400 hepatitis B surface antigen-positive Alaska native carriers. Arch Intern Med 1990; 150(5):1051-1054

2. Liu J, Yang HI, Lee MH, et al. Incidence and determinants of spontaneous hepatitis B surface antigen seroclearance: a community-based follow-up study. Gastroenterology 2010;139(2): 474-482

3. Sampliner RE, Hamilton FA, Iseri OA, et al. The liver histology and frequency of clearance of the hepatitis B surface antigen (HBsAg) in chronic carriers. Am J Med Sci 1979;277(1):17-22

4. Janssen HL, van Zonneveld M, Senturk H, et al. Pegylated interferon alpha-2b alone or in combination with lamivudine for $\mathrm{HBeAg-positive} \mathrm{chronic} \mathrm{hepatitis} \mathrm{B:} \mathrm{a} \mathrm{randomised} \mathrm{trial.} \mathrm{Lancet}$ 2005;365(9454):123-129

5. Chang TT, Lai CL, KewYoon S, et al. Entecavir treatment for up to 5 years in patients with hepatitis $\mathrm{B}$ e antigen-positive chronic hepatitis B. Hepatology 2010;51(2):422-430

6. Heathcote EJ, Marcellin P, Buti M, et al. Three-year efficacy and safety of tenofovir disoproxil fumarate treatment for chronic hepatitis B. Gastroenterology 2011;140(1):132-143

7. Yuen MF, Wong DK, Sablon E, et al. HBsAg seroclearance in chronic hepatitis B in the Chinese: virological, histological, and clinical aspects. Hepatology 2004;39(6):1694-1701

8. Loriot MA, Marcellin P, Walker F, et al. Persistence of hepatitis $\mathrm{B}$ virus DNA in serum and liver from patients with chronic hepatitis B after loss of HBsAg. J Hepatol 1997;27(2):251-258

9. Yuen MF, Wong DK, Fung J, et al. HBsAg seroclearance in chronic hepatitis B in Asian patients: replicative level and risk of hepatocellular carcinoma. Gastroenterology 2008;135(4):1192-1199

10. Simonetti J, Bulkow L, McMahon BJ, et al. Clearance of hepatitis B surface antigen and risk of hepatocellular carcinoma in a cohort chronically infected with hepatitis B virus. Hepatology 2010; 51(5):1531-1537

11. Kim H, Oh EJ, Kang MS, et al. Comparison of the Abbott Architect i2000 assay, the Roche Modular Analytics E170 assay, and an immunoradiometric assay for serum hepatitis B virus markers. Ann Clin Lab Sci 2007;37(3):256-259

12. Mühlbacher A, Weber B, Bürgisser P, et al. Multicenter study of a new fully automated HBsAg screening assay with enhanced sensitivity for the detection of HBV mutants. Med Microbiol Immunol 2008;197(1):55-64

13. Matsubara N, Kusano O, Sugamata Y, et al. A novel hepatitis B virus surface antigen immunoassay as sensitive as hepatitis B virus nucleic acid testing in detecting early infection. Transfusion 2009;49(3):585-595
14. Weber B. Genetic variability of the $S$ gene of hepatitis B virus: clinical and diagnostic impact. J Clin Virol 2005;32(2):102-112

15. Kimura T, Rokuhara A, Sakamoto Y, et al. Sensitive enzyme immunoassay for hepatitis B virus core-related antigens and their correlation to virus load. J Clin Microbiol 2002;40(2):439-445

16. Wong DK, Tanaka Y, Lai CL, et al. Hepatitis B virus core-related antigens as markers for monitoring chronic hepatitis B infection. J Clin Microbiol 2007;45(12):3942-3947

17. Rokuhara A, Tanaka E, Matsumoto A, et al. Clinical evaluation of a new enzyme immunoassay for hepatitis B virus core-related antigen; a marker distinct from viral DNA for monitoring lamivudine treatment. J Viral Hepatitis 2003;10(4):324-330

18. Shinkai N, Tanaka Y, Matsuura K, et al. Evaluation and application of a newly developed highly sensitive HBsAg chemiluminescent enzyme immunoassay for chronic hepatitis B patients. Rinsho Byori 2010;58(11):1078-1084

19. Shinkai N, Tanaka Y, Matsuura K, et al. Evaluation and application of a novel high-sensitive chemiluminescent enzyme immunoassay for chronic hepatitis B patients with HBsAg seroconversion. Hepatology 2010;52(4):458A (abstract)

20. Chu CM, Liaw YF. HBsAg seroclearance in asymptomatic carriers of high endemic areas: appreciably high rates during a longterm follow-up. Hepatology 2007;45(5):1187-1192

21. Brechot C, Thiers V, Kremsdorf D, et al. Persistent hepatitis B virus infection in subjects without hepatitis $\mathrm{B}$ surface antigen: clinically significant or purely "occult"? Hepatology 2001;34(1): 194-203

22. Yuen MF, Lee CK, Wong DK, et al. Prevalence of occult hepatitis B infection in a highly endemic area for chronic hepatitis B: a study of a large blood donor population. Gut 2010;59(10): 1389-1393

23. Seo DH, Whang DH, Song EY, et al. Prevalence of antibodies to hepatitis B core antigen and occult hepatitis B virus infections in Korean blood donors. Transfusion 2011;51(8):1840-1846

24. Hou J, Wang Z, Cheng J, et al. Prevalence of naturally occurring surface gene variants of hepatitis B virus in nonimmunized surface antigen-negative Chinese carriers. Hepatology 2001;34(5): $1027-1034$

25. Verheyen J, Neumann-Fraune M, Berg T, et al. Mutations in the HBs-antigen influence the results of HBsAg quantification assays. J Hepatol 2011;54(Suppl):S158 (abstract).

26. Gilbert RJ, Beales L, Blond D, et al. Hepatitis B small surface antigen particles are octahedral. Proc Natl Acad Sci USA 2005; 102(41):14783-14788

27. Fung J, Lai CL, Yuen MF. Hepatitis B virus DNA and hepatitis B surface antigen levels in chronic hepatitis B. Expert Rev Anti Infect Ther 2010;8(6):717-726

28. Vanlandschoot P, Leroux-Roels G. Viral apoptotic mimicry: an immune evasion strategy developed by the hepatitis B virus? Trends Immunol 2003;24(3):144-147

29. Dienes HP, Gerlich WH, Worsdorfer M, et al. Hepatic expression patterns of the large and middle hepatitis B virus surface proteins in viremic and nonviremic chronic hepatitis B. Gastroenterology 1990;98(4):1017-1023

30. Werle-Lapostolle B, Bowden S, Locarnini S, et al. Persistence of cccDNA during the natural history of chronic hepatitis B and decline during adefovir dipivoxil therapy. Gastroenterology 2004; 126(7): $1750-1758$

31. Volz T, Lutgehetmann M, Wachtler P, et al. Impaired intrahepatic hepatitis $\mathrm{B}$ virus productivity contributes to low viremia in most HBeAg-negative patients. Gastroenterology 2007;133(3): $843-852$

32. Thompson AJ, Nguyen T, Iser D, et al. Serum hepatitis B surface antigen and hepatitis B e antigen titers: disease phase influences correlation with viral load and intrahepatic hepatitis B virus markers. Hepatology 2010;51(6):1933-1944 
33. Bill CA, Summers J. Genomic DNA double-strand breaks are targets for hepadnaviral DNA integration. Proc Natl Acad Sci USA 2004;101(30):11135-11140

34. Fung J, Lai CL, Young J, et al. Quantitative hepatitis B surface antigen levels in patients with chronic hepatitis B after 2 years of entecavir treatment. Am J Gastroenterol 2011;10:1766-1773

35. Yeo W, Johnson PJ. Diagnosis, prevention and management of hepatitis B virus reactivation during anticancer therapy. Hepatology 2006;43(2):209-220
36. Moucari R, Martinot-Peignoux M, Mackiewicz V, et al. Influence of genotype on hepatitis B surface antigen kinetics in hepatitis B e antigen-negative patients treated with pegylated interferonalpha2a. Antivir Ther 2009;14(8):1183-1188 